\title{
ANALISIS PENINGKATKAN KEMAMPUAN PEMECAHAN MASALAH DAN KEMANDIRIAN BELAJAR DAMPAK FLIPPED CLASSROOM BERBANTUAN VIDEO PEMBELAJARAN
}

\author{
Marista Sari ${ }^{1}$, Bambang Sri Anggoro ${ }^{2}$, Iip Sugiharta ${ }^{3}$ \\ 1,2,3 Universitas Islam Negeri Raden Intan Lampung \\ maristasariayi11051998@gmail.com,bambangsrianggoro@radenintan.ac.id, \\ iipsugiharta@radenintan.ac.id
}

\begin{abstract}
A good education will create a good generation so that the lives of nations and countries will have a good effect. The purpose of this research is to analyze the influence of flipped classroom learning models assisted by Video Learning to improve problem solving skills and learning independence. The research method used is quantitative with quasy experimental design type. The sampling techniques in this study used randomized classroom techniques as experiment classes with flipped classroom learning models, control classes that used expository models. The data analysis technique used in this study is the Manova test with the conclusion that there is an influence on the use of flipped classroom learning models assisted by learning videos to improve solving skills. There is an influence on the use of flipped classroom learning models assisted by learning videos to improve learning independence. There is an influence on the use of flipped classroom learning models assisted by learning videos to improve mathematical problem solving skills and learning independence.
\end{abstract}

Key Words: Flipped Classroom; troubleshooting; independent learning

Abstrak: Pendidikan yang baik akan menghasilkan generasi yang baik sehingga kehidupan berbangsa dan bernegara berdampak baik. Tujuan penelitian ini adalah menganalisis pengaruh model pembelajaran flipped classroom berbantuan Video Learning terhadap peningkatan keterampilan pemecahan masalah dan kemandirian belajar. Metode penelitian yang digunakan adalah kuantitatif dengan tipe desain quasy eksperimental. Teknik pengambilan sampel dalam penelitian ini menggunakan teknik kelas acak sebagai kelas eksperimen dengan model pembelajaran flipped classroom, kelas kontrol yang menggunakan model ekspositori. Teknik analisis data yang digunakan dalam penelitian ini adalah tes Manova dengan kesimpulan bahwa terdapat pengaruh penggunaan model pembelajaran flipped classroom berbantuan video pembelajaran untuk meningkatkan keterampilan pemecahan. Terdapat pengaruh penggunaan model pembelajaran flipped classroom berbantuan video pembelajaran untuk meningkatkan kemandirian belajar. Terdapat pengaruh penggunaan model pembelajaran flipped classroom berbantuan video pembelajaran untuk meningkatkan keterampilan pemecahan masalah matematis dan kemandirian belajar.

Kata Kunci: Kelas Terbalik; Penyelesaian Masalah; Kemandirian Belajar 
PENDAHULUAN

Teknologi sangat berperan penting didunia pendidikan (Dian dkk., 2019). Seperti di zaman era modern seperti ini yang kemajuan tehnologi semakin berkembang pesat sehingga tehnologi yang telah hadir tidak bisa dihindari lagi (Ngafifi, 2014). Pendidikan harus mengikuti perkembangan zaman yang ada. Karena pendidikan merupakan sarana untuk menuju kepada pertumbuhan dan perkembangan bangsa. Pendidikan juga merupakan investasi sumber daya manusia jangka panjang yang mempunyai nilai strategis bagi kelangsungan peradaban manusia di dunia (Sakina, 2016). Tidak dapat dipungkiri bahwa perkembangan teknologi komunikasi dan informasi yang telah berlangsung begitu cepat, telah menyebabkan sejumlah perubahan yang besar pada masyarakat. (Regita dkk., 2018). Dikarenakan dunia memasuki era revolusi 4.0 dimana teknologi informasi dan komunikasi dimanfaatkan sepenuhnya (Hasanah dkk., 2019). Pendidikan merupakan hal yang penting dalam kehidupan. Setiap individu membutuhkan pendidikan baik yang muda tua sekarang dan selamanya manusia pasti sangat membutuhkan pendidikan. Dengan demikian untuk menghasilkan manusia yang berkualitas dan mampu bersaing pendidikan harus benar-benar diarahkan (Bambang, 2016)

Adapun Flipped classroom Mengunakan video pembejaran dapat membuat proses belajar lebih efektif, bisa melatih kemandirian untuk menemukan dan memahami konsep dalam menyelesaikan masalah (Juniantari dkk., 2019). Rendahnya kemampuan pemecahan masalah matematis dikarenakan pembelajaran yang kurang efektif terutama kurangnya jam pelajaran. Untuk mengatasi permasalahan tersebut perlu adanya pembelajaran inovasi terbaru (Fifit dkk., 2019) Pemecahan masalah menjadi sasaran menggunakan pengetahuan, pemahaman dan keterampilan yang telah diperoleh untuk menyelesaikan masalah pada situasi baru. Oleh sebab itu kemampuan pemecahan masalah penting dalam proses pembelajaran (Ariawan dkk., 2017), Supaya dapat mengoptimalkan pembelajaran yang dapat mempengaruhi kemampuan pemecahan masalah matematika, perlu memahami suatu konsep ketelitian, ketekunan dan kesabaran.

Pembelajaran flipped classroom diduga memberikan dampak yang cukup baik bagi peserta didik dengan Tingkat kemampuan pemecahan masalah dan kemandirian belajar peserta didik yang diajarkan dengan model pembelajarn flipped classroom lebih tinggi dibandingkan pada model pembelajaran ekspositori (Ario dkk., 2019). Pembelajaran ekspositori efektif dilakukan jika tidak ada sarana dan prasarana, peserta didik sulit dalam memahami materi yang disampaikan dan peserta didik memiliki tingkat kesulitan yang sama (Ismail dkk., 2013). Dari uraian permasalah di atas peneliti mengharapkan dampak positif dari model pembelajaran flipped classroom berbantuan video 
pembelajaran terhadap peningkatan masalah dan kemandirian belajar. Keterbaruan dalam penelitian terletak pada model pembelajaran flipped classroom berbantuan video pembelajaran.

\section{TINJAUAN TEORETIS}

Flipped classroom adalah model pembelajaran yang terpusat pada peserta didik sehinggadapat meningkatkan kemampuan belajar dalam proses belajar mangajar. (Herry dkk., 2016). Model pembelajaran yang terbalik metode tradisional, dimana biasanya diberikan di kelas dan peserta didik mengerjakan tugas di rumah (Muhammad dkk., 2019).

Adapun langkah-langkah flipped classroom adalah:

1. Mengajarkan peserta didik terlebih dahulu cara bagaimana mengakses dan menonton video serta mencatat hal-hal yang penting dalam video pembelajaran tersebut tersebut.

2. Menggarahkan peserta didik menonton video pembelajaran dirumah sebelum memulai pelajaran materi tertentu.

3. Meminta peserta didik memberikan pertanyaan yang menarik saat didalam kelas untuk memastikan apaakah peserta didik sudah melihat video pembelajaran

4. Memberikan tugas individu maupun kelompok kepada peserta didik. Tugas yang diberikan agar peserta didik lebih memahami materi tersebut, dimana pendidik sebagai fasilitator membantu peserta didik jika mengalami kesulitan. kemampuan

pemecahan

5. Mengarahkan peserta didik untuk saling tolong menolong jika mengalami kesukaran walaupun pendidik berperan sebagai fasilitator.

6. Penarikan kesimpulan bersamasama dari proses pembelajaran yang telah dilaksanakan

Kemampuan pemecahan masalah sangatlah penting dalam matematika, bagi mereka yang akan menerapkannya, baik dalam bidang studi lain maupun dalam kehidupan sehari-hari di kemudian hari akan mendalami atau mempelajari matematika (Fatimah dkk., 2016). Tujuan dari pemecahan masalah yaitu menciptakan proses berfikir peserta didik dapat menerapkan di dalam kehidupan sehari-hari (Dinni, 2018). Pemecahan masalah adalah suatu usaha mencari jalan keluar dari suatu tujuan yang tidak begitu mudah segera dapat dicapai.

Kemandirian belajar yang mempengaruhi hasil belajar matematika peserta didik yang berasal dari alam diri berupaya secara mandiri dalam menggali informasi belajar dari sumber belajar. Kemandirian diperlukan agar peserta didik mempunyai tanggung jawab dalam mengatur dan mendisiplinkan dirinya (Aini, 2016), selain itu dalam mengembangkan kemampuan belajar atas kemauan sendiri. Dengan demikian kemandirian belajar peserta didik akan memiliki tujuan yang jelas, dapat menilai diri sendiri, mempertimbangkan kemajuan belajar seperti pan dangan dan kepercayaan 
yang tinggi tentang kemampuan dirinya, menilai pembelajaran, faktor yang mempengaruhi dalam belajar dan antisipasi dampak selama pembelajaran berlangsung. Kemandirian belajar juga mengeharusan dan tuntutan. Kemandirian belajar merupakan suatu

\section{METODOLOGI PENELITIAN}

Penelitian ini menggunakan model pembelajaran flipped classroom merupakan penelitian eksperimen. Jenis penelitianya menggunakan quasi exsperiment design. Kelompok kontrol adalah kelompok yang mendapatkan perlakuan model ekspositori se dangkan kelompok eksperimen adalah kelompok yang menggunakan model pembelajaran flipped classroom. Populasi yang digunakan peneliti yaitu peserta didik VII SMPN 02 Air Hitam tahun pelajaran 2020/2021 dari kelas VII B dan VII D.Tehnik sampling yang digunakan adalah tehnik cluster random sampling yang dilakukan secara acak sebagai wakil dari populasi. Tehnik pengumpulan data bisa didapat melalui dua cara yaiu tes perubahan seseorang untuk melakukan aktivitas belajar. Dengan cara mandiri atas dasar motivasinya sendiri dan merupakan hasil dari latihan sendiri tanpa bergantung pada orang dan dapat digunakan untuk memecahkan masalah yang sedang dihadapi.

kemampuan pemecahan masalah dan non tes. Instrumen yang digunakan peneliti untuk mengukur kemampuan pemecahan masalah adalah tes uraian (essay) dan menggunakan angket untuk kemandirian belajar. Instrumen yang baik harus memenuhi persyaratan yang penting yaitu uji validitas, uji tingkat kesukaran, uji daya beda dan uji reabilitas. Tehnik analisis data uji ngain untuk mengetahui terdapat selisih antara nilai pretest dan posttest, menunjukan peningkatan pemahaman atau penguasaan konsep peserta didik setelah melakukan pembelajaran dilakukan pendidik. Uji hipotesis yang digunakan adalah manova menggunakan program R. Adapun langkah-langkah model pembelajaran flipped classroom adalah:

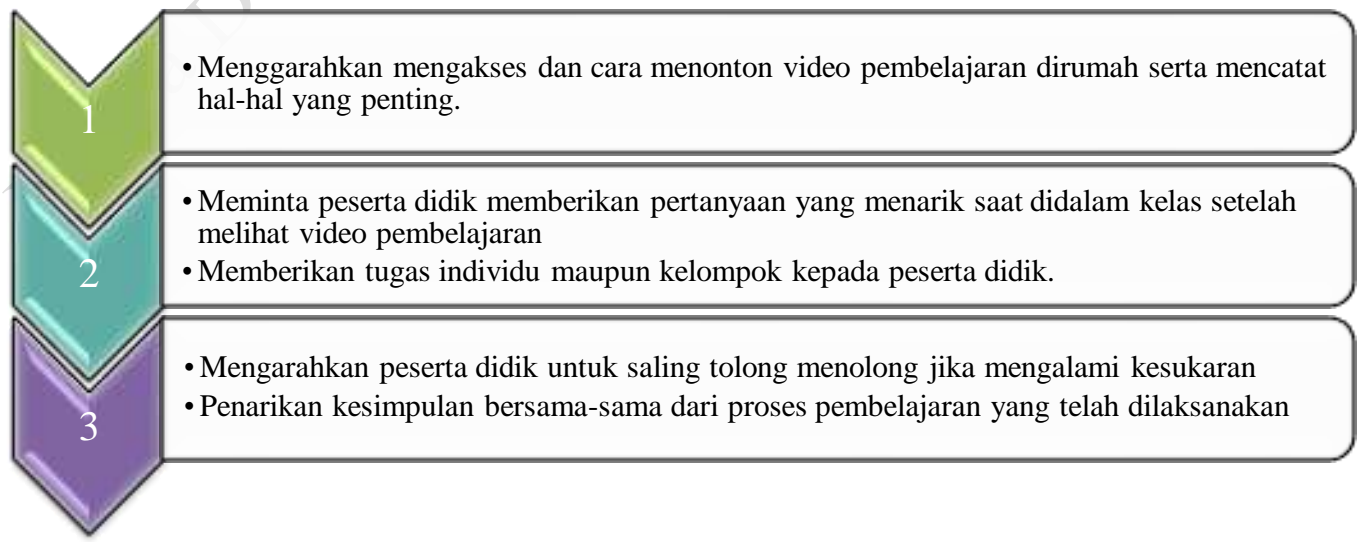

Gambar 1.

Langkah-Langkah Model Pembelajaran Flipped Classroom 
Berikut alur penelitian yang kemampuan pemecahan maslah dan dilakukan untuk meningkatkan kemandirian belajar :

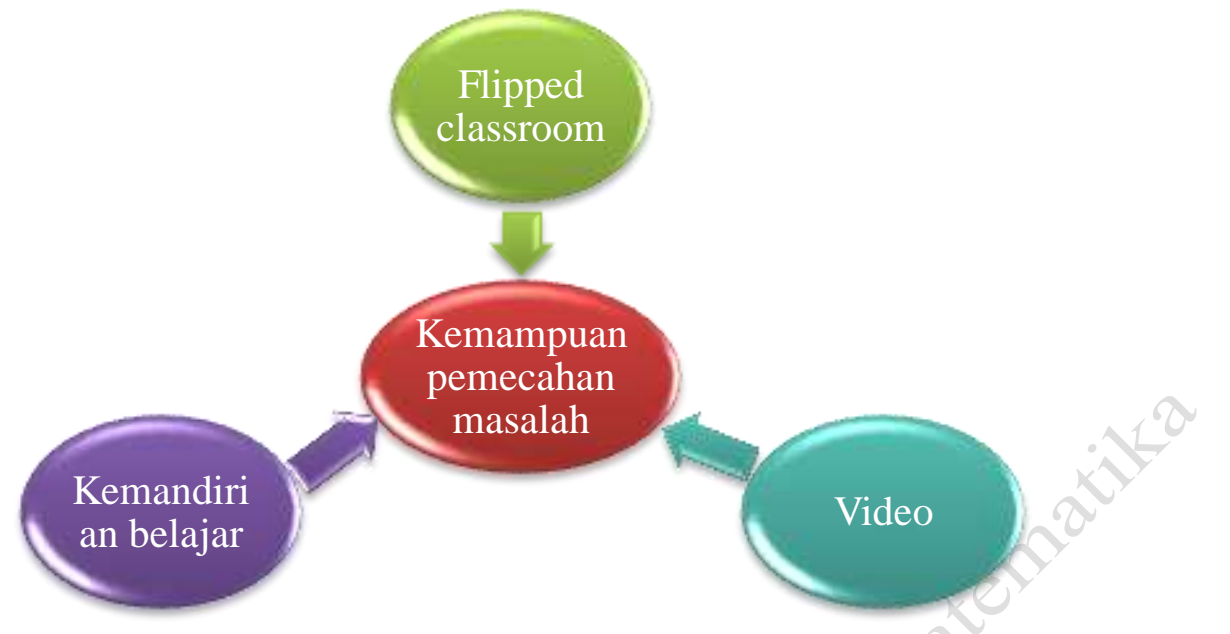

\section{Gambar 2. Alur Penelitian}

\section{HASIL DAN PEMBAHASAN}

Instrumen dalam penelitian ini meliputi tes kemampuan pemecahan masalah matematis dan angket kemandirian belajar peserta didik. Sebelum dilakukan analisis data angket kemandirian belajar dan tes kemampuan pemecahan masalah matematis, maka terlebih dahulu akan dilakukan uji coba instrumen. Angket kemandirian belajar tidak dilakukan uji coba dikarenakan angket tersebut diambil dari angket yang telah valid serta reliabel oleh peneliti terdahulu dan dapat digunakan untuk mengukur tingkat kemandirian belajar peserta didik dalam penelitian ini. Setelah penelitian selesai di lakukan, maka dari hasil pre-test dan hasil pos-test pada kelas kontrol dan eksperimen maka dapat mencari nilai $\mathrm{n}$-gain dengan cara mencari selisih nilai pos-test dan pretest kemudian dibagi skor maksimal di kurang pre-test. Data nilai n-gain dapat dirangkum dalam tabel 1 berikut:

Tabel 1.

\section{Deskripsi Data Amatan N-Gain Kemampuan Pemecahan Masalah Matematika}

\begin{tabular}{lccccccc}
\multirow{2}{*}{ Kelompok } & \multirow{2}{*}{$X_{\max }$} & \multirow{2}{*}{$X_{\min }$} & \multicolumn{2}{c}{ Ukuran Terdentasi Sentral } & \multicolumn{2}{c}{$\begin{array}{c}\text { Ukuran Variansi } \\
\text { Kelompok }\end{array}$} \\
\cline { 4 - 8 } & & & $\bar{x}$ & $M_{o}$ & $M_{e}$ & $\mathrm{R}$ & $\mathrm{S}$ \\
\hline Eksperimen & 100 & 54,84 & 74,73 & 100 & 74,13 & 45,16 & 14,02 \\
\hline Kontrol & 85,71 & 28,57 & 54,34 & 50 & 51,47 & 57,14 & 14,14 \\
\hline
\end{tabular}

Kesimpulannya bahwa hasil n-gain lebih tinggi dari hasil n-gain kemampuan pemecahan masalah kemampuan pemecahan masalah kelas matematis pada kelas eksperimen yang kontrol. Pengambilan data angket menerapkan model pembelajaran dilakukan sebelum dan setelah flipped classroom berbantuan video pembelajaran untuk melihat tingkat 
kemandirian belajar peserta didik pada dirangkum dalam Tabel 2 berikut:

kelas kontrol dan eksperimen yang

Tabel 2

Deskripsi Data Amatan N-Gain Angket Kemandirian Belajar

\begin{tabular}{cccccccc}
\hline \multirow{2}{*}{ Kelompok } & $\mathbf{X}_{\max }$ & $\mathbf{X}_{\min }$ & \multicolumn{2}{c}{ Ukuran Terdensi Sentral } & \multicolumn{2}{c}{$\begin{array}{c}\text { Ukuran Variansi } \\
\text { Kelompok }\end{array}$} \\
\cline { 4 - 8 } & & $\overline{\mathbf{x}}$ & $\mathbf{M}_{\mathbf{0}}$ & $\mathbf{M}_{\mathbf{e}}$ & $\mathbf{R}$ & $\mathbf{S d}$ \\
\hline
\end{tabular}

Eksperime

\begin{tabular}{llllllll}
$\mathrm{n}$ & 80 & 21,05 & 45,51 & 21,05 & 44,56 & 58,95 & 18,09 \\
\hline Kontrol & 65 & 8,63 & 29,73 & 23,64 & 26,11 & 56,37 & 12,29 \\
\hline
\end{tabular}

Berdasarkan Tabel 2 , hasil n- berdistribusi normal dan populasi yang gainangket kemandirian belajarpada sama atau homogen, maka langkah kelas eksperimen didapatkan selanjutnya akan

Kesimpulannya bahwa hasiln-gain dilakukan pengujian hipotesis. angket kemandirian belajarpada kelas Uji hipotesis dalam penelitian ini eksperimen yang menerapkan model menggunakan uji Manova pembelajaran flipped classroom (Multivariate Analysis of Variance). berbantuan video lebih tinggi dari hasil Perhitungan uji Manova (Multivariate $\mathrm{n}$-gain angket kemandirian belajarpada Analysis of Variance) dalam penelitian kelas kontrol. Setelah diketahui data ini menggunakan program $R$. penelitian berasal dari populasi

Tabel 3

Deskripsi Data Amatan Perhitungan Uji Manova

\begin{tabular}{|c|c|c|c|c|}
\hline Pengaruh & & $\operatorname{Pr}(>\mathrm{f})$ & $\mathrm{p}$-value & Keputusan \\
\hline \multirow{3}{*}{$\begin{array}{l}\text { Model } \\
\text { pembelajaran } \\
\text { flipped classroom } \\
\text { berbantuan video } \\
\text { pembelajaran }\end{array}$} & $\begin{array}{l}\text { Pemecahan } \\
\text { masalah }\end{array}$ & $4.78 \mathrm{e}-07 * * *$ & 0 & $H_{0}$ ditolak \\
\hline & $\begin{array}{l}\text { Kemandirian } \\
\text { belajar }\end{array}$ & $\begin{array}{c}\operatorname{Pr}(>\mathrm{F}) \\
0.0005517 * * *\end{array}$ & 0 & $\mathrm{H}_{0}$ ditolak \\
\hline & $\begin{array}{l}\text { Kemampuan } \\
\text { pemecahan } \\
\text { masalah }\end{array}$ & $3.42 \mathrm{e}-06 * * *$ & 0 & $\mathrm{H}_{0}$ ditolak \\
\hline
\end{tabular}

Berdasarkan hasil pada program $\mathrm{R}$ dapat dilihat bahwapada baris model pembelajaran terhadap kemampuan pemecahan masalah matematis $\operatorname{Pr}(>\mathrm{F}) 4.78 \mathrm{e}-07 * * *$ dilihat dari signifikasi nilai $* * *$ adalah 0 akan diperoleh nilai $p$ - Value yaitu sebesar 0 dengan derajat angka signifikansi yang dipakai yaitu 0,05 . Hal tersebut menunjukkan bahwa $p$-Value < 0,05, sehingga $H_{0 A}$ ditolak dan $H_{1 A}$ diterima. Kesimpulannya bahwa terdapat pengaruh penerapan model pembelajaran Flipped Classroom berbantuan video pembelajaran terhadap kemampuan pemecahan masalah matematis.

Intepretasi pada baris model pembelajaran terhadapkemandirian belajar peserta didik diperoleh dari $\operatorname{Pr}(>\mathrm{F}) \quad 0.0005517 * * *$ menghasilkan *** yang berarti dilihat dari signif nya *** adalah 0 maka akan diperoleh nilai $p$-Value yaitu sebesar Odengan derajat angka signifikansi yang dipakai yaitu 0,05 . Hal tersebut menunjukkan bahwa $\quad p$-Value $<0,05$, sehingga $H_{0 B}$ ditolak dan dan $H_{1 B}$ 
diterima. Kesimpulannya bahwa terdapat pengaruh penerapan model pembelajaran Flipped Classroom berbantuan video terhadap kemandirian belajar peserta didik.

Selanjutnya dari model pembelajaran terhadap kemampuan pemecahan masalah matematis dan kemandirian belajar peserta didik secara bersamaan (silmultan). Uji Multivariat tersebut dilakukan menggunakan program $R$. diperoleh $\mathrm{Pr}$ $3.42 \mathrm{e}-06 * * *$ menghasilkan $* * *$ dilihat dari signif adalah 0 maka akan diperoleh nilaip - Value yaitu sebesar 0 dengan derajat angka signifikansi yang dipakai yaitu 0,05. Sehingga $H_{0 C}$ ditolak dan $H_{1 C}$ diterima. Kesimpulannya bahwa terdapat pengaruh penerapan model pembelajaran flipped classroom berbantuan video terhadap kemampuan pemecahan masalah matematis dan kemandirian belajar peserta didik.

Model pembelajaran flipped classroom yang terpusat pada peserta didik sehingga dapat meningkatkan kemampuan belajar dalam proses belajar mangajar (Loizou ., 2020). Kegiatan model flipped classroom di luar kelas tidak hanya menonton video pembelajaran, namun peserta didikharus menjawab soal-soal latihan yang bersifat tertutup dan ketika di dalam kelas dilakukan kemampuan tanya jawab serta diskusi untuk memecahkan masalah yang bersifat terbuka (Namaziandost dkk., 2020). Sehingga model pembelajaran flipped classroom berbantuan media video yang menampilkan gambar dan suara dalam waktu yang bersamaan yang bertujuan untuk menyampaikan pesan atau informasi. Penelitian ini menggunakan model pembelajaran yang berbantuan video yaitu berupa video pembelajaran yang akan ditonton oleh peserta didik.
Proses pembelajaran model pembelajaran flipped classroom berbantuan video dimulai dari tahap pendidik mengajarkan peserta didik terlebih dahulu cara bagaimana mengakses dan menonton video serta mencatat hal-hal yang penting dalam video pembelajaran tersebut tersebut. Kemudian pendidik menggarahkan peserta didik menonton video pembelajaran dirumah sebelum memulai pelajaran materi tertentu. Pendidik meminta peserta didik memberikan pertanyaan yang menarik saat didalam kelas.

Selanjutnya pendidik memastikan apakah peserta didik sudah melihat video pembelajaran pendidik memberikan pertanyaan kepada peserta didik sehingga mereka dapat berdiskusi dan diberikan tugas individu. Tugas yang diberikan agar peserta didik lebih memahami materi tersebut, dimana pendidik sebagai fasilitator membantu peserta didik jika mengalami kesulitan. Pendidik kemudian mengarahkan peserta didik untuk saling tolong menolong jika mengalami kesukaran walaupun peserta didik berperan sebagai fasilitator. Pada akhir proses pembelajaran, menyimpulkan bersama-sama dari proses pembelajaran yang telah dilaksanakan.

Berdasarkan uraian yang telah dijelaskan, Adapun faktor lainya yang menjadi penyebab kemampuan pemecahan masalah matematis dan kemandirian belajar peserta didik lebih baik dengan pengajaran model pembelajaran flipped classroom berbantuan video dibandingkan dengan pengajaran model pembelajaran konvensional. (Madaio dkk., 2020). Hal tersebut diduga karena kegiatan model pembelajaran flipped classsroom di luar kelas tidak hanya menonton video pembelajaran, tetapi peserta didik diarahkan untuk 
menyelesaikan beberapa masalah yang bersifat tertutup dan kegiatan tanya jawab serta diskusi di dalam kelas untuk memecahkan masalah bersifat terbuka.

Model pembelajaran flipped classroom dalam penelitian ini juga berbantuan media video. Model pembelajaran yang berbantuan video yaitu berupa video pembelajaran yang akan ditonton oleh peserta didik, sehingga membuat peserta didik terlihat antusias dalam mengerjakan soal, peserta didik saling berlomba untuk mengerjakan soal yang ada. Penerapan model pembelajaran flipped classroom berbantuan video juga membuat peserta didik lebih terarah dalam proses diskusi kelompoknya. Ketika peserta didik dapat mengikuti seluruh tahapan dengan baik, maka peserta didik akan dapat memahami dan menyelesaikan setiap permasalahan matematika dengan baik.

Setelah kegiatan pembelajaran selesai dan materi telah tersampaikan, maka peneliti memberikan soal pretest dan posttest serta angket kemandirian belajar kepada peserta didik. Pretest dan posttest dilakukan untuk melihat nilai peningkatan kemampuan pemecahan masalah dan angket kemandirian belajar yang akan digunakan untuk mengetahui adakah terdapat pengaruh penggunaan model pembelajaran flipped classroom berbantuan video dalam meningkatkan kemampuan pemecahan masalah matematis dan kemandirian belajar peserta didik. (Amalia dkk., 2020). Peserta didik memiliki tanggapan dan respon terhadap model pembelajaran flipped classroom berbantuan video yang baik, hal ini menunjukkan jika peserta didik tertarik terhadap penerapan model pembelajaran flipped classroom berbantuan video pada materi bentuk aljabar.
Ketertarikan peserta didik pada model pembelajaran flipped classroom berbantuan video terlihat dari suasana saat proses kegiatan belajar mengajar $(\mathrm{KBM})$, dimana peserta didik merasa nyaman, termotivasi, semangat dan terlihat aktif dalam belajar dikelas serta mampu berkomunikasi dengan baik dalam menerima materi yang telah disampaikan oleh peneliti. Akan tetapi, masih terdapat peserta didik yang pasif ketika diterapkannya model pembelajaran flipped classroom berbantuan videoyaitu pada saat peserta didik menyampaikan hasil diskusi kelompok, dimana ada beberapa peserta didik yang kurang percaya diri dalam menyampaikan hasil diskusi. Secara menyeluruh, peserta didik dapat merespon dan memahami materi dengan baik pada saat diterapkannya model pembelajaran flipped classroom berbantuan video.

Proses pembelajaran pada kelas kontrol diawali dengan pemberian materi oleh peneliti kepada peserta didik dan selanjutnya peserta didik diarahkan oleh peneliti untuk memperhatikan materi yang dipelajari. Peserta didik hanya mendengar, menyimak dan mencatat apa yang disampaikan oleh peneliti. (Ulandari dkk., 2019).

Kegiatan pembelajaran pada kelas kontrol yang menerapkan model pembelajaran ekspositori sudah berjalan dengan baik, Dimana beberapa peserta didik terlihat aktif dalam bertanya ketika peneliti menjelaskan materi dan memberikan soal latihan tentang materi bentuk aljabar. Akan tetapi, masih banyak peserta didik yang tidak fokus, mengobrol, tidak mencatat, mengantuk dan mencontek atau menyalin hasil latihan temen sebelahnya ketika kegiatan belajar berlangsung. Setelah materi 
pembelajaran tentang bentuk aljabar telah tersampaikan, sama halnya dengan kelas eksperimen, kelas kontrol juga diberikan soal pretest dan posttest untuk mengetahui peningkatan kemampuan pemecahan masalah matematis serta angket untuk melihat kemandirian belajar peserta didik peserta didik.

Berdasarkan hal tersebut, peserta didik yang telah diterapkan model pembelajaran flipped classroom berbantuan video menghasilkan kemampuan pemecahan masalah matematis dan kemandirian belajar peserta didik yang lebih baik serta dapat mengoptimalkan potensi yang ada dalam diri setiap peserta didik dibandingkan dengan pembelajaran menggunakan model pembelajaran konvensional (ekspositosi). (Yasin dkk., 2020). Hasil penelitian tersebut memperlihatkan bahwa peserta didik yang memperoleh model pembelajaran flipped classroom berbantuan video lebih baik kemampuan pemecahan masalah matematis dan kemandirian belajarnya daripada pembelajaran menggunakan model pembelajaran ekspositori.

Hasil yang diperoleh peneliti juga selaras dengan penelitian sebelumnya yang menggunakan model pembelajaran flipped classroom oleh Jahangir Mohammadi, Hossein Barati, \& Manijeh Youhanaee, hasil yang didapatkan bahwa pembelajaran dengan model pembelajaran Flipped Classroom efektif untuk meningkatkan prestasi belajar dan komunikasi peserta didik. (Mohammadi dkk., 2019)

Selanjutnya penelitian oleh Pınar Girmen \&Mehmet Fatih Kaya, hasil yang didapatkan bahwa pembelajaran menggunakan model pembelajaran flipped classroom dapat mengasah danmeningkatkan keterampilan bahasa dasar dan aktivitas pengayaan.
(Girmen,, 2019). Berikutnya penelitian oleh Mohamad Yahya Abdullah, Supyan Hussin, \& Kemboja Ismail, hasil yang didapatkan bahwa pembelajaran menggunakan model pembelajaran flipped classroom dapat mengasah dan meningkatkan kinerja berbicara bahasa Inggris. (Abdullah dkk., 2019).

Berdasarkan hasil penelitian tersebut, maka didapatkan suatu hubungan antara kedua variabel terikat dalam penelitian ini, yaitu kemampuan pemecahan masalah matematis dan kemandirian belajar. Penelitian ini dapat menghasilkan data yang lebih baik dan dapat meningkatkan kemampuan pemecahan masalah matematis dan kemandirian belajar peserta didik. Hasil penelitian terhadap kemampuan pemecahan masalah matematis juga selaras dengan hasil penelitian kemandirian belajar peserta didik, dimana penelitian ini dapat meningkatkan kemampuan pemecahan masalah matematis dan kemandirian belajar peserta didik. (Simamora dkk., 2018)

Kesimpulannya yaitu jika kemampuan pemecahan masalah matematis peserta didik meningkat, maka dapat dikatakan juga bahwa kemandirian belajar peserta didik juga meningkat. Hal sama juga dapat kita lihat yaitu jika kemandirian belajar peserta didikmeningkat, maka kemampuan pemecahan masalah matematis juga akan meningkat. Kemampuan pemecahan masalah matematis dan kemandirian belajar adalah kemampuan matematika yang sangat penting dan harus dikuasai, karena kemampuan pemecahan masalah matematis dan kemandirian belajar peserta didik yang baik akan dapat menunjang peserta didik dalam belajar dan menyelesaikan berbagai permasalahan matematika. 


\section{SIMPULAN DAN SARAN}

Kesimpulan akhir yang diperoleh dalam penelitian ini adalah sebagai berikut: Terdapat pengaruh penggunaan model pembelajaran flipped classroom berbantuan video pembelajaran terhadap kemampuan pemecahan masalah matematis dan kemandirian belajar peserta didik pada materi bentuk aljabar. Kemampuan pemecahan masalah matematis dan kemandirian belajar peserta didik menggunakan model pembelajaran flipped classroom berbantuan video pembelajaran lebih baik dibandingkan menggunakan model pembelajaran ekspositori.

Berdasarkan hasil penelitian menggunakan model pembelajaran flipped classroom berbantuan video pembelajaran terdapat beberapa saran yang ingin disampaikan oleh peneliti kepada beberapa pihak yang terkait dalam penelitian ini : Peneliti lanjutan yang berniat untuk menerapkan model pembelajaran flipped classroom berbantuan video pembelajaran alangkah baiknyadapat mempersiapkan materi pembelajaran dengan sebaik mungkin dikarenakan tidak semua mata pelajaran dapat menggunakan model pembelajaran ini dan diharapkan dapat memilih waktu yang tepat guna meperoleh hasil yang terbaik. Peneliti juga harus mempertimbangkan beberapa faktor yang dapat mempengaruhi kemampuan pemecahan masalah matematis dan kemandirian belajar peserta didik sehingga keterbatasan dalam penelitian yang akan dilakukan dapat diminimalisir untuk penelitian berikutnya.

\section{DAFTAR PUSTAKA}

Abdullah, M. Y. Hussin, S. \& Ismail, K. (2019). Implementation of flipped classroom model and its effectiveness on English speaking performance. International Journal of Emerging Technologies in Learning, 14(9), 130-147.

Aini, P. N. \& Taman, A. (2012). Pengaruh kemandirian belajar dan lingkungan belajar siswa terhadap prestasi belajar akuntansi siswa kelas xi ips sma negeri 1 sewon bantul tahun ajaran 2010/2011. Jurnal Pendidikan Akuntansi Indonesia, 10(1).

Amalia, P. R. Sukestiyarno, Y. L. \& Cahyono, A. N. (2020). ProblemSolving Skill Based on Learning Independence Through Assistance in Independent Learning with Entrepreneurial-nuanced Modules. Unnes Journal of Mathematics Education Research, 11(1), 102108.

Ariawan, R. \& Nufus, H. (2017). Hubungan Kemampuan Pemecahan Masalah Matematis dengan Kemampuan Komunikasi Matematis Siswa. Jurnal THEOREMS (The Original Research of Mathematics), 1(2).

Ario, M. \& Asra, A. (2018). Pengaruh pembelajaran flipped classroom terhadap hasil belajar kalkulus integral mahasiswa pendidikan matematika. Anargya: Jurnal Ilmiah Pendidikan Matematika, 1(2), 82-88.

Bambang, S. A. (2016). Meningkatkan Kemampuan Generalisasi Matematis Melalui Discovery Learning dan Model Pembelajaran PeerLed Guided Inquiry. Jurnal 
Pendidikan Matematika, 7(1), 1120.

Cahyani, H. \& Setyawati, R. W. (2017). Pentingnya peningkatan kemampuan pemecahan masalah melalui PBL untuk mempersiapkan generasi unggul menghadapi MEA. PRISMA, Prosiding Seminar Nasional Matematika, 151-160.

Dian Rahadian, Gina Rahayu, dan R. R. O. (2019). Teknologi Pendidikan Kajian Aplikasi Ruangguru Berdasarkan Prinsip dan Paradigma Interaksi Manusia dan Komputer. Pendidikan Teknologi Informasi, 5(1), 11.

Digdoyo, E. (2019). Rumah Puspo Budaya Nusantara Sebagai Pusat Pengembangan Pendidikan Karakter Melalui Tari Nusantara. Integralistik, 30(1).

Dimas, I. (2019). Pendidikan Agama Islam Dalam Revolusi Industri 4.0. Prosiding Seminar Nasional Prodi PAI UMP.

Dinni, H. N. (2018). HOTS (High Order Thinking Skills) dan kaitannya dengan kemampuan literasi matematika. PRISMA, Prosiding Seminar Nasional Matematika, 1, 170-176.

Effendi, L. A. (2012). Pembelajaran matematika dengan metode penemuan terbimbing untuk meningkatkan kemampuan representasi dan pemecahan masalah matematis siswa SMP. Jurnal Penelitian Pendidikan, 13(2), 1-10.

Fatimah, A. E. (2016). Peningkatan Kemampuan Pemecahan Masalah Matematis dan Kemandirian Belajar Siswa SMK Negeri 1 Percut Sei Tuan Melalui Pendekatan Differentiated Instruction. MES: Journal of Mathematics Education and Science, 2(1).
Girmen, P. \& Kaya, M. F. (2019). Using the Flipped Classroom Model in the Development of Basic Language Skills and Enriching Activities: Digital Stories and Games 1. International Journal of Instruction, 12(1), 555572.

Hakim, D. L. (2020). Kecerdasan Logis Matematis Siswa SMP pada Scaffolding. Prosiding Sesiomadika, 2(1).

Hasanah, U. N.,Thahir, A. Komaruddin, K. \& Rahmahwaty, R. (2019). MURDER Learning and Self Efficacy Models: Impact on Mathematical Reflective Thingking Ability. Journal for the Education of Gifted Young Scientists, 7(4), 1123-1135.

Herry, N. D., Sutama, "Efektivitas Clipped Classroom Terhadap Sikap dan Keterampilan Pelajar Matematika," Managemen Pendidikan 11, no. 2 (2016), h.3

Ismail, A. K. Sugiman, S. \& Hendikawati, P. (2013). Efektivitas Model Pembelajaran Teams Group Tournament (Tgt) Dengan Menggunakan Media "3 In 1" Dalam Pembelajaran Matematika. Unnes Journal of Mathematics Education, 2(2).

Jamun, Y. M. (2018). Dampak teknologi terhadap pendidikan. Jurnal Pendidikan dan Kebudayaan Missio, 10(1), 48-52.

Juniantari, M. Pujawan, I. G. N., \& Widhiasih, I. D. A. G. (2019). Pengaruh pendekatan flipped classroom terhadap pemahaman konsep matematika siswa SMA. Journal of Education Technology, 2(4), 197-204.

Koerniantono, K. (2018). STRATEGI PEMBELAJARAN. SAPA-Jurnal Kateketik dan Pastoral, 3(1), 126142. 
Loizou, M. \& Lee, K. (2020). A flipped classroom model for inquiry-based learning in primareducation context. Research in Learning Technology, 28(1063519), 1-18.

Madaio, M. A.,Yarzebinski, E., Kamath, V. Zinszer, B. D. Hannon-Cropp, J. Tanoh, F. Akpe, Y. H. Seri, A. B. Jasińska, K. K. \& Ogan, A. (2020). Collective Support and Independent Learning with a Voice-Based Literacy Technology in Rural Communities. Conference on Human Factors in Computing Systems - Proceedings, $3,1-14$.

Mashuri, I. (2016). Pengaruh pembelajaran berbasis masalah dan inkuiri ditinjau dari kemandirian belajar siswa kelas $\mathrm{X}$ SMA Negeri kabupaten Blora. Journal of Mathematics and Mathematics Education, 2(1).

Mohammadi, J. Barati, H., \& Youhanaee, M. (2019). The Effectiveness of Using Flipped Classroom Model on Iranian EFL Learners' English Achievements and Their Willingness to Communicate. English Language Teaching, 12(5), 101-115.

Muhammad Syahril Harahap, Silvana Dewi, "Efektifitas Model Pembelajaran Plipped Classroom Terhadap cdKemampuan Penalaran Matematis Siswa," MathEdu 2, no. 3 (2019), h. 98.

Namaziandost, E. \& Çakmak, F. (2020). An account of EFL learners' self-efficacy and gender in the Flipped Classroom Model. Education and Information Technologies, 25, 4041-4055.

Ngafifi, M. (2014). Kemajuan teknologi dan pola hidup manusia dalam perspektif sosial budaya. Jurnal Pembangunan Pendidikan: Fondasi dan Aplikasi, 2(1).
Nurdyansyah, N. \& Aini, Q. (2017). Peran Teknologi Pendidikan Pada Mata Pelajaran Matematika Kelas Iii Di Mi Ma'arif Pademonegoro Sukodono. At-Thullab: Jurnal Pendidikan Guru Madrasah Ibtidaiyah, 1(1), 124-140.

Nurhayati, E. (2016). Penerapan scaffolding untuk pencapaian kemampuan pemecahan masalah matematis. JP3M (Jurnal Penelitian Pendidikan dan Pengajaran Matematika), 2(2), 107-112.

Regita A. Bambang, S.A., Indra, G.(2018). Pengembangan media komik berbasis android pada pokok bahasa gerak lurus. Indonesian journal of science and matematick education, 1(1), 53-57.

Ronda, D. (2019). Kepemimpinan Kristen Di Era Disrupsi Teknologi. Evangelikal: Jurnal Teologi Injili dan Pembinaan Warga Jemaat, $3(1), 1-8$.

Rusydi Ananda. (2017). Perkembangan Tehnologi Pembelajaran dan Pengaruhnya Terhadap Perkembangan Peserta Didik. Managemen Pendidikan danKeislaman, 6(1), 69.

Sahi, A. (2019). Penerapan Layanan Akademik dalam Pemanfaatan Teknologi Cloud Computing. TEMATIK-Jurnal Teknologi Informasi dan Komunikasi, 6(1), 65-74.

Sakina, W. Y. Imam, S. Iip, S.(2016). Video Pembelajaran Matematika Berbasis Microsoft Power point 2016 Berbantuan Blender 3d. Pendidikan Matematika, 515-525

Sartika, R. A. D. (2012). Penerapan komunikasi, informasi, dan edukasi gizi terhadap perilaku sarapan siswa Sekolah Dasar. Kesmas: National Public Health Journal, 7(2), 76-82. 
Sigit Priatmoko. (2018). Memperkuat Ekssitensi Pendidikan Islam Di Era 4.0. Pendidikan Islam, 1(2), 221.

Simamora, R. E. Saragih, S. \& Hasratuddin, H. (2018). Improving Students' Mathematical Problem Solving Ability and Self-Efficacy through Guided Discovery Learning in Local Culture Context. International Electronic Journal of Mathematics Education, 14(1), 61-72.

Tsuaiban Al ayalamiyah, Punaji Setysari, dan H. P. (2019). Blended Learning dan Kemandirian Belajar Mahasiswa Tehnologi Pendidikan. Kajian Tehnologi Pendidikan, 2(2), 2.

Ulandari, L., Amry, Z., \& Saragih, S. (2019). Development of Learning Materials Based on Realistic Mathematics Education Approach to Improve Students' Mathematical Problem Solving Ability and Self-Efficacy. International Electronic Journal of Mathematics Education, 14(2), 331-340.

Ulya, M. R., Isnarto, I. Rochmad, R., \& Wardono, W. (2019). Efektivitas
Pembelajaran Flipped Classroom dengan Pendekatan Matematika Realistik Indonesia terhadap Kemampuan Representasi Ditinjau dari Self-Efficacy. PRISMA, Prosiding Seminar Nasional Matematika, 2, 116-123.

Walidah, Z., Wijayanti, R., \& Affaf, M. (2020). The Pengaruh Model Pembelajaran Flipped Classroom (FC) terhadap Hasil Belajar. Edumatica: Jurnal Pendidikan Matematika, 10(2), 71-77.

Yasin, M. Fakhri, J. Siswadi, Faelasofi, R., Safi'i, A. Supriadi, N. Syazali, M. \& Wekke, I. S. (2020). The effect of SSCS learning model on reflective thinking skills and problem solving ability. European Journal of Educational Research, 9(2), 743-752.

Yolanda, F. Sriwahyuni, T. L. Rohima, S. \& Maharani, P. (2020). Problematika pendidikan di sekolah daerah pesisir. Seminar Nasional Peningkatan Mutu Pendidikan,1(1). 